原著

長期経過を追えたレルモワイエ症候群の 1 例

関

$$
\begin{aligned}
& \text { 聡- 犬飼 賢也 } \text { 渡辺 一道 } \\
& \text { 高橋紳一郎・高橋 姿 }
\end{aligned}
$$

\title{
Long-term Follow-up of a Case of Lermoyez's Syndrome
}

Satoshi Seki, Kenya Inukai, Kazumichi Watanabe, Shinichirou Takahashi, Sugata Takahashi

Department of Otolaryngology, Niigata University Faculty of Medicine

We report a patient with Lermoyez's syndrome who was followed up for 9 years and whose hearing activity was well maintained. The main pathological factor in this case was considered to be endolymphatic hydrops, judging from such findings as positive glycerol test, repeated vertigo attacks like Meniere disease and well-maintained hearing activity under Isosorbide therapy. Since Dilazep dihydrochloride was also effective in preserving good hearing function, disturbance of vascular circulation might have played a role in the pathology of this case.

Key words: Lermoyez, Isosorbide, long-term

\section{はじめに}

レルモワイエ症候群はメニエール病と同じくめ まい, 耳鳴, 難聴を主症状とするるのの, メニエー ル病とはめまいと蝸牛症状の起こる順序が逆で, めまい発作をきっかけに聴力が急速に回復するも のである1。レルモワイエ症候群の発症機序に関 する報告は散見できるが2\} 112，聴力子後の報告に ついてはまれである。今回われわれは長期にわた り経過を観察でき，良好な聴力レベルを維持でさ ている非常にまれなレルモワイエ症候群を報告す る。

\section{症例}

症例：61歳，女性。

現病歴：1990年より左耳鳴，難聴を繰り返して いた。1994年 4 月頃から左難聴，耳鳴に続いてめ まいが出現し，その直後に左難聴が改善するレル

新潟大学医学部耳鼻咽喉科学教室
モワイエ症候を $5 \sim 6$ 回繰り返すため，10月当科 紹介された。

既往歴，家族歴：特記すべき事項なし。

現症：耳鼻咽喉科局所所見, 血液学的所見侍 記すべき事項なし。純音聴力検査は図 1 のごとく であった。平衡機能検查では自発, 注視眼振, 頭 位眼振険査で所見はなく，温度眼振検査では冷温 交互法で右 canal paresis（CP）31\%，振子様回転 検査に左右差はみられなかった。視標追跡検査で は，水平・垂直とも平滑，視運動性眼振検查では 水平・垂值とも解発良好であった。脳 MRI 検查 に異常は認められなかった。12月8日のグリセ ロールテストは図 2 のごとく陽性であった。蝸電 図検査で有意なーSP の上昇はなかった。

経過：レルモワイエ症候を伴った左メニエール 病としてイソソルビド，循環改善剤，ビタミン剤 による治療を開始した。聴力経過（3 分法平均聴 力）では1995年 1 月 12 日に聴力低下を認めたが, 


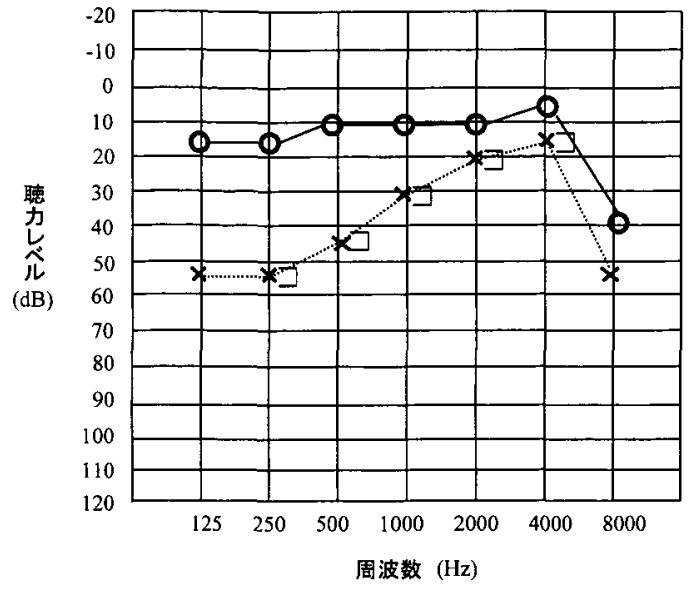

図 1 聴力検查所見（'94年10月）

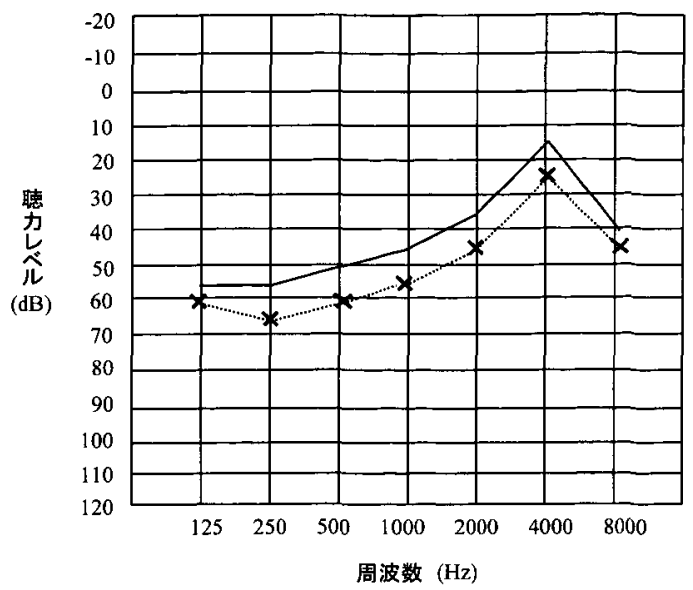

図 2 グリセロールテストの結果（'94年12月）

$\times$ : 左グリセロールテスト前聴力,

実線：左グリセロールテスト後聴力。

症候は認めなかった。1998年 8 月のめまい発作は 左聴力低下を伴ったメニエール病様発作で，左向 き水平回旋混合性眼振，振子様回転検査で左 $16 \%$

循環改善剤, ビタミン剤, ステロイド剤の点滴に て 2 月 9 日に聴力は改善した（図 3 ）。以降子数 回にわたり聴力低下を認めた。1996年11月，1998 年 8 月にはめまい発作を伴ったが，レルモワイエ
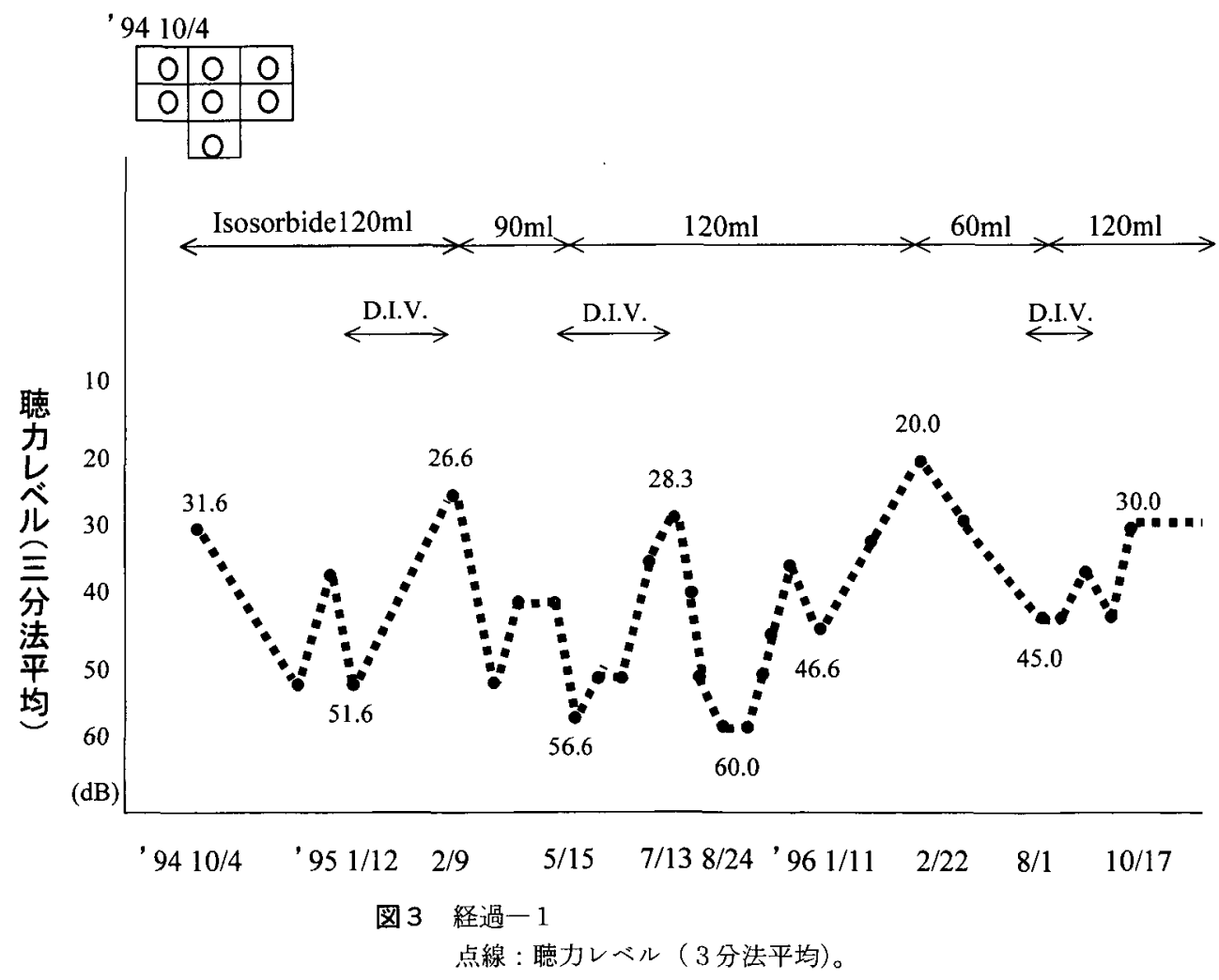


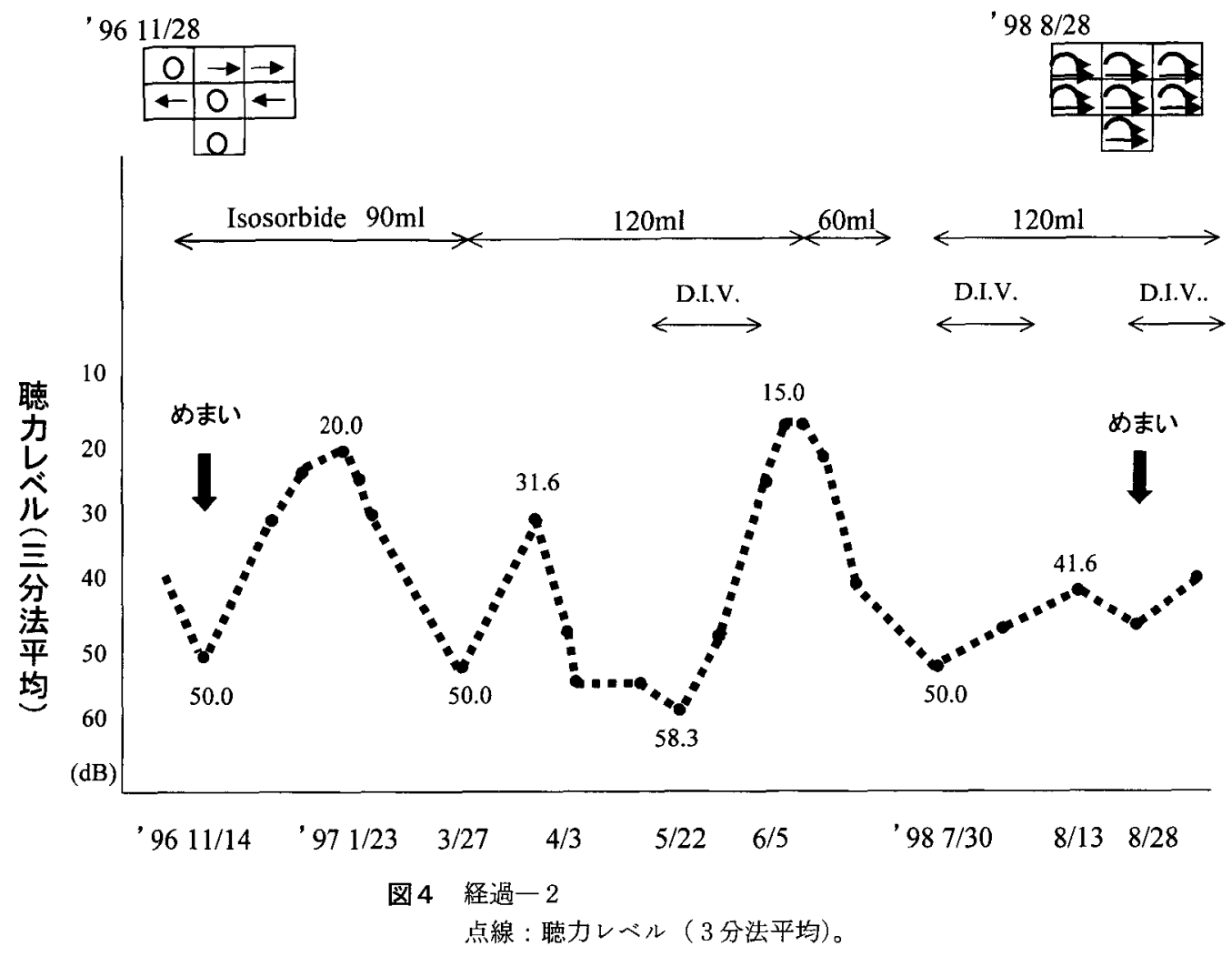

directional preponderance（DP）を認めた。いずれ の聴力低下時においても循環改善剂, ビタミン剂, ステロイド阂の点滴ないしはイソソルビド内服治 療にて聴力は回復した。また聴力低下から改善を で $2 \sim 15$ 週間（平均 7 週間）と比較的長期間を要 した（図 3，4）。1998年10月15日左難聴を訴え再 診し, 純音聴力検査にて $53.3 \mathrm{~dB}$ の左低音障害型 感音難聴を認めた。自発, 頭位眼振はなく振子様 回転検査に特記すべき所見はなかった。循環改善 剂, ビタミン剂，イソソルビド内服にて加療を開 始したところ，10月29日めまい発作直後に左難聴 の改善を訴采受診, 純音聴力検査で $30 \mathrm{~dB}$ に聴力 改善を認めたため，本症例をレルモワイエ症候群 と診断した。この時, 右向き水平回旋混合性眼振, 振子様回転検査で右 $20 \% \mathrm{DP}$ を認めた。その後も 数回の聴力低下を認めたが，イソソルビド, 循環 改善剂などの内服を継続し，現在は塩酸ジラゼプ など内服としているが，2003年 8 月左聴力レベル は $20 \mathrm{~dB}$ と正常に保たれている(図5)。

\section{考察}

レルモワイエ症候群の病態としては内リンパ 厈の緩やかな上昇に伴い蝸牛症状が出現し膜迷路 の破綻とともに，急速に内耳圧が改善しめまいが 生じるとする内リンパ化上昇説》10)，また内耳動 脈の卛縮に伴い内耳循環障害が生じ蝸牛症状を呈 し，循環障害が改善する際に中枢による前庭機能 代償が保たれなくなりめまいが生じ，それととも に聴力が回復するとする循環障害説(15)8)，あるい は前 2 者の両者によって発生するとする折克説 などが考えられている。武田ら ${ }^{4)}$ は自験例の一側 例と両側例とを比較しその病態の違いから，一側 例ではバトロトキシン投与によって聴力が改善し たことから循環障害が関与し，両側例では内リン パ水腫や虚脱などの水分代謝異常が関与するので はないかと推測している。われわれの症例は長期 間にわたりメニエール病に類似した発作を反復し ていること，グリセロールテスト陽性であり内り ンパ水腫の存在が示唆されること，イソソルビド 長期投与により正常聴力まで回復していることか 


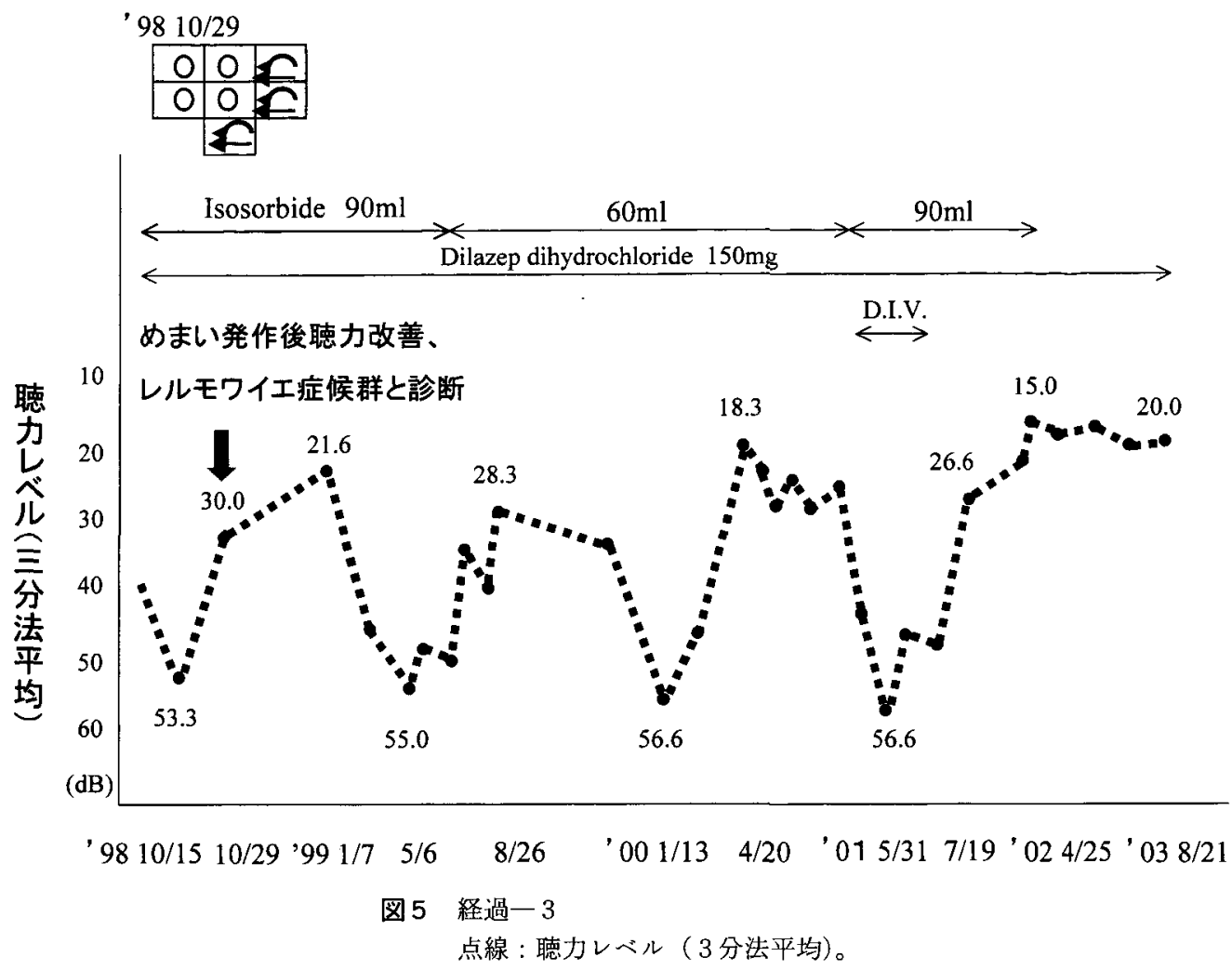

ら内リンパ王の変動により発作が発生しているも のと考えられた。

また本症例ではメニエール病発作時には患側に 向から眼振がみられているが，レルモワイエ症候 発作直後は健側に向から眼振がみられている。眼 振の力向からの病態検討では, Young ら゙はレル モワイエ症候発作時に患側に向から眼振を認め 翌日健側に向から眼振を認めていることからメ二 エール病と同様の内リンパ水腫が病態であろうと 推測し，武田ら4)の一側性症例では循環障害説が 関与すると推測されているが，レルモワイエ発作 数時間後に患側に向から眼振を認めて括り刺激性 眼振であろらと推測している。その後聴力改善は 数日後も継続しているが眼振は健側に変化してい る。その他の症例でも眼振が健側に向からもの ( $^{8}$, 患側に向からもの3 -5)9) などに分かれ，眼振方向 から病態を推測することは困難と考えられる。

レルモワイエ症候群の病態について聴力回復に 要する期間からの検討はない。本症例では長期間 の聴力低下後に突然聴力が回復する場合や聴力が
変動しながら徐々に回復する場合があり, 聴力回 復には $2 \sim 15$ 週間 (平均 7 週間) を要している。 Schoonhoven $5^{12)}$, Eggermont $5^{13)}$, Schmidt $5^{14)}$ の症例でる数日〜 6 力月とメニエール病患者の聴 力回復とは異なり比較的長期間を要している。循 環障害が要因の一つと考えられている突発性難聴 では，治癒，著明回復群では治療開始14日目まで に急激に回復するものが多いとされており 15 ，本 症例の病態として偱環障害説を考えると聴力回復 は難しいはずであるが，現在でもほぼ正常聴力を 保っている。すなわち，本症例ではイソソルビド 長期投与などにより内りンパ圧の上昇が持続的に 軽減され聴力が回復したと考えるのが適当と推察 されるが、それでもすべての病態は説明できない。 Schmidt ら ${ }^{14)}$ も現在のところレルモワイエ症候群 の病態を説明できるモデルはないとしている。

このようにレルモワイエ症候群の病態について は聴力ならびに眼振経過から推測してもまだ不明 な点が多く個々の症例によっても異なり，今後も 検討を要すると考兄られた。 
本症例では内リンパ圧上昇説が主な病態と考兄 られたが，現在ではイソソルビド内服は中止し， 塩酸ジラゼプなどの循環改善剂を投与しているが 聴力低下はみられていないことや内リンパ水腫の 成因自体にも循環障害の関与が疑われている6) こ とからも循環障害説の一部関与もあるのではない かと考光られた。

\section{まとめ}

9 年間にわたり経過を観察し聴力がに茿正常に 保たれている非常にまれなレルモワイエ症候群の 1 例を報告した。本症例の病態は内リンパ圧上昇 により起こっていると考えられたが，一部循環障 害による関与る示咥された。

本論文の要旨は第61回日本めまい平衡医学会 （2002年10月，富山）に必いて発表した。

\section{文献}

1) Lermoyez $\mathrm{M}$ : Le vertige qui fait entendre. $\mathrm{La}$ Presse Medicale 27: 1-3, 1919

2) Xenellis JE, Linthicum FH, Galey ER: Lermoyez's syndrome: Histopathologic report of a case. Ann Otol Rhinol Laryngol 99: 307-309, 1990

3 ) Young $\mathrm{YH}, \mathrm{Wu} \mathrm{CH}$ : Electronystagmographic findings in a case of Lermoyez's syndrome. Auris Nasus Larynx 21: 118-121, 1994

4）武田憲昭, 肥塚 泉, 土井勝美, 他 : 両側お よび一側レルモワイエ症候群症例と発症機序 に関する考察. 日耳鼻 99: 277-285, 1996

5）安田宏一：レルモワイ工症候群一文献的考察 と自験 2 症例一。 日耳鼻 75: 1353-1361, 1972

6）神崎 化，高橋正紘：レルモワイエ症候群の 発現機序に関する一考察. 耳喉 48: 615-621, 1976
7 ) 西川益利, 西川恵子:レルモワイエ症候群例. 耳鼻臨床 85: 881-885, 1992

8 ）朴沢二郎, 鎌田重輝, 高木明子, 他：レル モワイ工症候群の成立機序に関する臨床的考 察. 耳鼻臨床 75: 1249-1253, 1982

9）町田敏之，甲藤洋一，暁 清文: Lermoyez 症候群の 1 症例. 耳喉 58: 917-918, 1986

10）池田元久，武藤二郎，渡辺 勈：レルモワイ 工症候群一自験例と症例報告のまとめ一。耳 鼻 35: 465-477, 1989

11）猪熊哲彦，関谷 透，兼定啓子，他：レル モワイエ症候群一症例とその発現機序一。 Equilibrium Res 45: 107-111, 1986

12) Schoonhoven R, Schmidt PH, Eggermont JJ: A longitudinal electrocochleographic study of a case of long-standing bilateral Lermoyez's syndrome. Eur Arch Otorhinolaryngol 247: 333 $-339,1990$

13) Eggermont JJ, Schmidt PH: Meniere disease: A long-term follow-up study of hearing loss. Ann Otol Rhinol Laryngol 94: 1-9, 1985

14) Schmidt PH, Schoonhoven R: Lermoyez's syndrome. A follow-up study in 12 patients. Acta Otolaryngol (Stockh) 107: 467-473, 1989

15）角田保雄, 大河内幸男, 唯木 享, 他 : 突発 性難聴の予後に関する検討. 耳鼻臨床 補 68: 81-87, 1993

\footnotetext{
原稿到着：平成15年 6 月 2 日

別刷請求先 : 関 聡

干951-8510 新潟市旭町通 1

新潟大学医学部耳鼻咽喉科学教室
} 